\title{
Para o estudo das origens da organização dos trabalhadores em Alagoas \\ periodizando o mutualismo
}

Osvaldo Batista Acioly Maciel

\section{SciELO Books / SciELO Livros / SciELO Libros}

MACIEL, OBA. Para o estudo das origens da organização dos trabalhadores em Alagoas:

periodizando o mutualismo. In: OLIVEIRA, TB., org. Trabalho e trabalhadores no Nordeste: análises e perspectivas de pesquisas históricas em Alagoas, Pernambuco e Paraíba [online]. Campina Grande: EDUEPB, 2015, pp. 85-112. ISBN 978-85-7879-333-3. Available from SciELO Books $<\underline{\text { http://books.scielo.org }>\text {. }}$

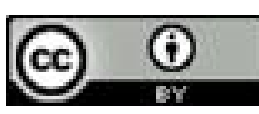

All the contents of this work, except where otherwise noted, is licensed under a Creative Commons Attribution 4.0 International license.

Todo o conteúdo deste trabalho, exceto quando houver ressalva, é publicado sob a licença Creative Commons Atribição $\underline{4.0}$.

Todo el contenido de esta obra, excepto donde se indique lo contrario, está bajo licencia de la licencia Creative Commons $\underline{\text { Reconocimento } 4.0 .}$. 


\section{Para o estudo das origens da organizaçáo dos trabalhadores em Alagoas: periodizando o mutualismo}

Osvaldo Batista Acioly Maciel

\section{INTRODUÇÁO}

Este texto discute sobre algumas questóes relacionadas aos meus estudos realizados no doutoramento ${ }^{1}$. Devido a uma série de opçóes tomadas ao longo da pesquisa e da execuçáo do projeto, o tema foi sendo delimitado cada vez mais. Apesar de, com tais encaminhamentos, o foco ficar cada vez mais preciso, o problema mais amplo continuava desafiando-me a buscar uma abordagem que favorecesse uma dialética de entendimento do objeto que não cancelasse a relaçáo com a totalidade. Nesses termos, mesmo que em forma ensaística, sem aprofundar mais alguns tópicos e sem a recorrência a evidências empíricas de modo acentuado, esboço aqui uma linha geral de desenvolvimento do que poderíamos chamar de formas de organização da classe trabalhadora em Maceió. Esse esboço, por se configurar como uma hipótese de trabalho que não foi confirmada em sua inteireza,

1 O projeto original apresentado à seleção intitulou-se Operários em Movimento: sociedades de trabalhadores e identificaçâoo de classe em Maceió (1870-1922), enquanto que a tese se restringiu ao mutualismo caixeiral: MACIEL, Osvaldo. A Perseverança dos caixeiros: o mutualismo dos trabalhadores do comércio em Maceió (1879-1917). Recife: Edufpe, 2011. Ao tempo da redação final deste texto, a tese estava concluída, porém ainda não fora defendida. Para fins de publicaçáo nessa coletânea, realizei tão somente uma revisão gramatical, reelaborei dois ou três parágrafos e acrescentei duas ou três notas. 
explora duas ordens de questão: a relação que a história social do trabalho estabelece com seus objetos e as principais fases da trajetória do mutualismo ao longo do surgimento e da construção do que se convencionou chamar de movimento operário ou, se se quiser, do sindicalismo moderno. Para tal empreitada, é preciso, ainda, indicar que o recorte espacial se concentra em Alagoas mais precisamente, em sua capital, Maceió - porém há remiçóes a outros casos ocorridos no Brasil e que podem servir para associar, comparar ou complementar a argumentação. Como fonte documental, recorro, principalmente, ao acervo da imprensa operária alagoana existente no Centro de Documentação e Memória da Universidade Estadual Paulista (Cedem-Unesp), e a algum material existente na Hemeroteca do Instituto Histórico e Geográfico de Alagoas (IHGA), bem como a relatórios e mensagens produzidos pelos governadores de Estado.

\section{O mutualismo e a História Social do Trabalho no Brasil}

Nos Cadernos do cárcere, Antonio Gramsci fala, em "diversos momentos de consciência política coletiva”. Para ele, num primeiro momento, teríamos um nível econômico-corporativo, em que o processo de identificação seria muito elementar, pois corresponderia à "unidade homogênea do grupo profissional e o dever de organizá-la, mas náo ainda a unidade do grupo social mais amplo." Em um segundo momento, temos um nível mais elevado, em que é atingida a "solidariedade de interesses" dentro de determinado grupo mais amplo como, por exemplo, entre todos os trabalhadores assalariados, independentemente de categoria. Por fim, num terceiro momento desse processo de articulação e tomada de consciência, a fase mais estritamente política, temos a superação do "círculo econômico", ou seja, da vinculaçáo objetiva com a esfera produtiva, e uma formulaçáo política e identitária de característica universal, formulando-se um projeto que se orienta para toda a sociedade ${ }^{2}$. Gramsci não utiliza essa

2 GRAMSCI, Antônio. Caderno 13 (1932/4): Breves notas sobre a política de Maquiavel. In: Cadernos do cárcere - v. 3 (editor: Carlos Nelson Coutinho). Tradução de Luiz Sérgio Henriques, Marco Aurélio Nogueira e Carlos Nelson Coutinho. Rio de Janeiro: Civilização Brasileira, 2000, p. 41. 
reflexão especificamente para formular um esquema de interpretação da evolução da organizaçáo dos trabalhadores, ou seja, das corporaçóes de ofício até os sindicatos propriamente ditos. Ele a utiliza para todas as formas de organização de classe, mesmo para as dominantes. Apesar dessa ressalva, creio que essa reflexão tem uma fortuna crítica que é retomada posteriormente pelos que se debruçam sobre a história operária e que pode nos ajudar a entender como tal esquema pode contribuir para se entender o desenvolvimento a que estou me referindo.

Vejamos a retomada dessa perspectiva a partir de E. P. Thompson, que a aplica, quase que literalmente, em seu ensaio sobre a cultura plebeia do Século XVIII inglês, analisando-a como uma cultura nem revolucionária nem deferente. Problematizando, em termos mais específicos, a formaçáo de uma longa tradição de organização dos trabalhadores, o historiador inglês identifica padrốes de continuidade legítimos de uma longa tradição sindical, por meio da avaliação de açóes, rituais, emblemas, solidariedades horizontais, conflitos com superiores etc., que envolviam guildas, sociedades estruturadas por ofício, sociedades de socorros mútuos, entre outras. Para ele, essa tradição articulava os costumes e os valores da plebe e de sua apariçáo política com os da difícil identidade da classe trabalhadora ${ }^{3}$. Após a pesquisa sobre o setecentos inglês, que o levou a reler as origens do sindicalismo, Thompson afirmou:

Agora já está claro que - se não há registro de organização contínua de sindicatos nacionais houve certamente uma tradição contínua de atividade sindical durante todo o Século [XVIII], e muito provavelmente (nos distritos têxteis) uma organização local contínua e uma liderança reconhecida para açóes que ora se disfarçavam de rough music, ora assumiam as máscaras protetoras

3 THOMPSON. Edward P. Patrícios e plebeus. In: Costumes em comum: estudos sobre a cultura popular tradicional. Tradução de Rosaura Eichemberg - São Paulo: Cia. das Letras, 1998 , p. 56-64. 
das sociedades de socorros mútuos. Essas tradições sindicalistas remontam ao Século XVII, e lamento que vários estudos recentes muito proveitosos deem uma impressão contrária ${ }^{4}$.

Como se vê, ao revisitar as reflexôes de Gramsci e complexificar sua análise, Thompson indica que, em um momento pré -industrial, quando não havia "classe trabalhadora" nem seus conflitos característicos, é preciso atentar para o "protoconflito", cuidando-se menos da "consciência de classe" e mais da "consciência de um ofício" . Dando um passo a frente, afirma que, no ambiente paternalista de entáo,

O sentimento de solidariedade de ofício podia ser forte. Mas a suposição de que essa fraternidade de ofício necessariamente entrasse em conflito com objetivos e solidariedades mais amplos é totalmente falsa. [...] O que a consciência de ofício pode inibir são as solidariedades econômicas entre diferentes grupos de produtores contra seus empregadores. Mas se pusermos de lado esse postulado anacrônico, encontraremos entre os trabalhadores e trabalhadoras do Século XVIII muitas evidências de solidariedade e consciências horizontais ${ }^{6}$.

Em suma, "as solidariedades náo eram segregadas pelos ofícios". Parece-me que, aqui, a leitura que Thompson faz dessa questấo, a partir de Gramsci, flexibiliza o caráter mais linear, de consolidação progressiva de novos níveis de consciência etc., imputado a esse processo pelo autor dos Cadernos do cárcere. Essa reelaboração gera a implicação de que tais níveis mais amplos de articulaçáo e consciência podem surgir mesmo numa etapa

Ibidem, p. 58. (Grifo meu).

Ibidem, p. 28.

Ibidem, p. 61-62. 
em que predomine a organização de trabalhadores por ofício. A partir dessa perspectiva, se a característica de uma noção mais ampla de reivindicaçóes, direitos, lutas e identidades encontra-se presente, retira-se o caráter necessariamente linear, que é, de um modo ou de outro, sugerido por Gramsci. Tem-se, então, uma formulação que daria conta de processos complexos, não necessariamente lineares, porém cheios de sentido histórico.

Como essa abordagem incide sobre a história do trabalho no Brasil? De que modo tais reflexóes podem ajudar a entender a forma como os trabalhadores começam a se organizar numa sociedade escravista, com um capitalismo que reproduz muitas formas de trabalho e sociabilidade que, grosso modo, estáo sendo superadas nos países industrialmente avançados?

No desenvolvimento recente da historiografia brasileira, o fenômeno do associativismo, em geral, e do mutualismo, em particular, tem se revelado um campo limite no que tange à especificidade da história social do trabalho. E como tal fenômeno toca diretamente em aspectos da história operária (pelo tipo de participação relevante e singular que os trabalhadores estabelecem com a cultura associativa e com as mutualidades), estudá-lo significa avançar em questóes teóricas e metodológicas importantes dessa história. Em outra vertente de atuaçáo, no entanto, quando tais fenômenos das sociedades de socorros mútuos (ou beneficentes) e do associativismo em geral perdem o ponto preciso de enfoque da história do trabalho e se esgarçam em direção a outros enfoques, podem levar ao abandono de uma percepção mais clara do que seja a formação da classe operária em determinada formação social.

Mesmo correndo o risco de uma excessiva simplificação, parece-nos haver duas grandes vertentes de interpretação da relaçáo do mutualismo com a história operária. De um lado, existe um grupo de historiadores que entende que a história do mutualismo ganha mais força analítica quando se considera a especificidade das sociedades de ajuda mútua organizada exclusiva ou 
predominantemente por trabalhadores ${ }^{7}$. De outro, temos os autores que afirmam não haver uma diferença básica entre os diversos tipos de associações mutuais, sejam elas operárias, teatrais, étnicas, por bairro, abertas etc. ${ }^{8}$.

Nesse novo contexto de produção historiográfica sobre o mutualismo, por exemplo, novos estudos identificam, com originalidade e pertinência, os laços horizontais de solidariedade estabelecidos entre diversos indivíduos no interior dessas associaçóes. Tal nova senda, trilhada por alguns estudos da história social no Brasil, vem enriquecendo os estudos sobre a formaçáo da classe. Entre outras questôes que são apontadas, está o estabelecimento de vínculos conjunturais ou duradouros entre classes e estratos distintos. Cabe, no entanto, considerar o sentido histórico de formação como algo direcional (sem ser linear) e que, por vezes, trabalhadores escolhem participar dessas alianças verticais muito mais por falta de opção do que por estratégia deliberada. Uma vez inserido nesse contexto de relaçóes clientelares, pelo menos em alguns casos, tentam livrar-se posteriormente delas, mas não conseguem plenamente. Alguém que, de cima (suponhamos um negociante estabelecido, proprietário de uma pequena fábrica ou algo parecido), decida participar de uma dessas entidades mutualistas de trabalhadores, por exemplo, poderá ao menos escolher não participar. A partir dessa decisão, sua vida não correrá riscos táo mais acentuados em função dessa opção. $\mathrm{O}$ mesmo não se dá com as classes subalternas: menos que o descenso social, quando um operário, um assalariado ou um artífice de origem humilde decide associar-se em uma sociedade de auxílio mútuo, o que está em jogo, muitas vezes, é a própria sobrevivência e a daqueles

7 Veja-se, entre outros, BATALHA, Claudio Henrique de Moraes. Sociedades de trabalhadores no Rio de Janeiro do Século XIX: algumas reflexóes em torno da formação da classe operária. In: Cadernos AEL: Sociedades operárias e mutualismo. Campinas, vol. 6, no 10/11, p. 41-66, 1999.

8 Veja-se, entre outros, VISCARDI, Cláudia Maria Ribeiro; JESUS, Ronaldo Pereira de. A experiência mutualista e a formação da classe trabalhadora no Brasil. In: FERREIRA, Jorge; REIS FILHO, Daniel Aarão (orgs). As esquerdas no Brasil - Vol. 1: A formação das tradições (1889-1945). Rio de Janeiro: Civilização Brasileira, 2007, p. 21-51. Para fazer a distinção entre essas duas vertentes historiográficas, ver MACIEL, Osvaldo. A Perseverança..., $o p$. cit., especialmente o primeiro capítulo. 
a quem a estrutura da sociedade em que está inserido não legou outras escolhas.

As pesquisas que realizo no âmbito dessa problemática para o universo empírico de Maceió convergem para a necessidade de um entendimento mais amplo do que é a formação da classe trabalhadora no Brasil. Nesse sentido, tanto a experiência das sociedades mutualistas de trabalhadores quanto a dos sindicatos e do 'movimento operário', em seu sentido estrito, fazem parte de interesses e preocupações que circundam minhas análises. Embora existam continuidades entre essas formas de organização operária, é preciso identificar as rupturas que marcam suas iniludíveis diferenças e em que condiçóes e conjunturas elas ocorrem.

Considerando não só o caso específico trabalhado em minha tese - o mutualismo caixeiral - mas também o surgimento e a ampliação das formas de resistência mais claras de várias outras categorias de trabalhadores em Maceió, analiso aqui as causas e os efeitos mais visíveis para o entendimento dessa ruptura ou, antes, dessa bifurcação de padróes organizativos, dessa nova tendência em germe que se desenvolveu posteriormente. Essa forma de encarar o problema da continuidade e da ruptura nas formas de organização dos trabalhadores serviu para encontrar balizas de períodos limites de análise do fenômeno do mutualismo como significativo para se compreenderem bem mais as virtudes e as vicissitudes contidas na história do mutualismo como parte da formação da classe trabalhadora. Em meus estudos, utilizo-me deliberadamente de uma abordagem que não construa oposiçóes radicais entre as formas mutuais de organização operária e as formas clássicas do sindicalismo moderno. Isso se deve ao modo extremamente complexo como ocorrem tais rupturas/bifurcaçóes, com uma série de permanências que impossibilitam a proposição de um paradigma de mudanças/modelo de aferição desse corte. Entre outros pontos, por exemplo, encontramos que a historiografia brasileira tem levantado vários exemplos de militantes de mutuais que terminam 'migrando' para sociedades de resistência e sindicatos com um sentido classista mais bem delimitado.

Efetivamente, na contínua conformação do cotidiano, é difícil 
não só a análise, mas também a identificação do posicionamento efetivo realizado pelos personagens que atuaram no processo histórico que está sendo estudado. As agruras do cotidiano geram as condiçôes de conscientização para que a mudança aconteça. Náo obstante, essa mudança - como ocorre na sucessáo de semanas que normalmente carregam diversos momentos de uma "rotina diária comum" - comporta também boa dose de "sobrevivência" de diversos aspectos culturais, inclusive de relacionamentos e compadrios pregressos, além de práticas e atividades avaliativas (e mesmo autoavaliativas) de valores e padróes de consciência e comportamento para determinadas situaçóes, lugares, eventos, pessoas e instituiçóes.

Assim, proponho que se percebam os níveis de diferenciação entre as formas mutual e sindical de organização dos trabalhadores a partir de algumas balizas de comparação entre ambas, destacando quatro delas:

A) A reivindicação de condiçóes de trabalho, salários, direitos, relaçôes contratuais etc. que indiquem contraposição explícita entre as categorias/classes envolvidas na negociação conflituosa: patróes e autoridades públicas, de um lado, e operários e empregados, de outro, etc. Essa postura de embates foi encontrada desde o período imperial ${ }^{9}$, porém só se disseminou e tornou-se comum entre as lideranças operárias no final do Século XIX;

B) A elaboraçáo de um discurso/ideologia que reflita uma consciência que não só articule uma identidade de classe/categoria positiva para os trabalhadores (artistas, operários, empregados, assalariados, etc.), mas também que o faça em contraposição expressa à outra classe/grupo social. $\mathrm{Ou}$, aprofundando essa consciência, que tal identidade seja articulada com a formulação alternativa a uma sociabilidade dada, nesse caso, a capitalista/liberal;

C) Um nível de autonomia material, tanto em termos de finanças quanto em termos organizacionais. No primeiro caso, isso

9 Veja-se, entre outros, a greve promovida pela Associação Tipográfica Fluminense em 1858, apresentada no início do segundo capítulo de VITORINO, Artur José Renda. Máquinas e operários: mudança técnica e sindicalismo gráfico (São Paulo e Rio de Janeiro, 1858-1912). São Paulo: Annablume/FAPESP, 2000. 
significa a conquista de uma sede própria ou alugada e, ainda, que os eventuais serviços e as atividades realizadas, como banda de música, espaços e ambientes de recreação etc., sejam mantidos, exclusiva ou preponderantemente, com recursos e forças próprios. Em termos organizacionais, as composiçóes das diretorias de eventual órgáo, dentre outras questóes, devem ser caracterizadas como independentes. Tais características ampliam os níveis de liberdade de forma tal que possibilitam o recurso desinibido às greves (mesmo curtas e sem mais ganhos efetivos), às comemoraçóes e às mobilizaçóes em torno do $1^{\circ}$ de maio e demais manifestaçóes de classe, realizadas no espaço público ou nos ambientes de trabalho, com conteúdo e forma classista mais nítidos;

D) É preciso que tais dimensões sejam alcançadas em um conjunto orgânico de práticas e manifestaçóes que demonstrem representatividade e legitimidade perante um coletivo de trabalhadores associados que seja amplo o suficiente em relação às bases daquela classe ou categoria, setor produtivo ou conjunto de categorias. Esse ponto, embora uma exigência de análise colocada aqui, termina sendo o que menos foi possível de ser verificado em minha pesquisa empírica.

Talvez o segundo item elencado acima seja o mais forte indicador de diferença da quebra de hegemonia existente entre as mutuais e as sociedades de resistência no mundo do trabalho. Portanto, centrarei a análise nessa dimensão. Efetivamente, está explícito nas principais formas de expressão para as mutuais, de modo geral, que a força da união, a convergência de interesses de seus associados e o esforço coletivo de seu corpo social produziriam, por si só, as melhorias de condições de vida e trabalho, bem como assegurariam uma velhice amparada. Assim, no interior das mutuais, as reclamaçóes pela não realização dos objetivos a que se propóem (ou, em alguns casos, as reclamaçóes oriundas de sua realização parcial) indicam como principal problema as divergências internas oriundas de indivíduos que não estão devidamente compenetrados dos valorosos ideais da sociedade, ou pela falta de interesse geral da categoria no sentido não só de se associar, mas também de se engajar efetivamente em tais demandas e projetos. 
No entanto, para as sociedades ditas de resistência, se esse sentido de união e coletividade é um problema destacado, ele não é único. Afinal, efetivamente, estaria em jogo também um conjunto de conflitos existentes na esfera mais ampla da sociabilidade por sua configuraçáo de classe, o que faria com que grupos sociais externos àquelas sociedades de trabalhadores obstaculizassem a realização desse desideratum e se opusessem frontalmente aos interesses da classe.

Em outros casos, numa configuração de análise mais reformista (ou evolucionista) acerca de tais questóes, teríamos que a essência do problema seria o modo hegemônico como a sociedade se organiza e se projeta. Nesse caso, náo haveria um grupo social específico como o empecilho para as realizaçóes da sociedade, mas o estado de evolução de toda aquela sociedade e o grau de civilização que teria alcançado. Nessa linha de argumentação, caberia identificar os aliados entre todos aqueles que lutam para que o progresso natural da sociedade náo seja emperrado, para que se chegue a um estágio em que efetivamente tais objetivos de classe sejam alcançados.

Como já frisado, a dificuldade de encontrar uma delimitação mais precisa entre essas duas hegemonias internas à forma de organizar a classe trabalhadora ocorre, efetivamente, com todo tipo de recorte historiográfico que se queira dar ${ }^{10}$. Várias práticas, rituais, lideranças consolidadas em mutuais reproduzem-se ou mesmo ganham vida nova ou formatação diferenciada no interior de entidades de resistência/classista. Em Alagoas, por exemplo, parece-nos que há um pequeno grupo de sócios das mutuais de trabalhadores que participam, conjunta ou posteriormente, das sociedades de resistência, como são os casos de Virgínio de

10 Como um exemplo que foi questionado com bastante pertinência, veja-se: MATTOS, Marcelo Badaró. Novos e velhos sindicalismos: Rio de Janeiro, 1955-1988. Rio de Janeiro: Vício de Leitura, 1998. 
Campos, Benedito Ângelo e Olympio Sant'Anna ${ }^{11}$. Essa não parece ser a regra, mas sim a exceção. Até onde pude averiguar, entre a primeira e a segunda décadas do Século XX, há um corte geracional, com o surgimento de novos líderes e militantes que aparecem no campo da organização dos trabalhadores apenas em sua forma classista mais explícita, sindicatos e uniôes operárias ${ }^{12}$. O que isso pode significar? Uma parte da historiografia tem interpretado esse dado para corroborar um recorte mais amplo entre as mutuais e o "sindicalismo moderno" como se não houvesse uma continuidade entre essas formas de agremiação operária. Gostaria de acrescentar alguns pontos que podem aprofundar o entendimento sobre o tópico ${ }^{13}$.

Parece-nos que essa majoritária distinção nominal/geracional de membros desses dois tipos de sociedade aponta para um aguçamento das relaçóes capitalistas e dos conflitos estabelecidos entre as classes, típicos dos grandes e dos médios espaços urbanos brasileiros no período estudado. Esse corte geracional pode sinalizar para uma experiência de apartação da escravidão que só os "moços" conhecem ${ }^{14}$, além do fato de que a federalização que

11 Marcelo Badaró Mattos encontra alguns trabalhadores engajados para o caso do Rio de Janeiro, onde, "em certos casos, é possível traçar quadros de convergência entre os esforços de associaçáo dos trabalhadores por um largo período de tempo", incluindo aí a atuação de lideranças de artistas e operários que militaram tanto nas hostes do mutualismo quanto na propaganda mais estritamente operária e/ou socialista, por exemplo, José Veiga, Otaviano Hudson e Vicente de Souza. Cf. MATTOS, Marcelo Badaró. Escravizados e livres: experiências comuns na formação da classe trabalhadora carioca. Rio de Janeiro: Bom Texto, 2008, p. 115-116.

12 Dentre outros, poderia citar os nomes de Manoel A. Soares, Oscar Silva, José Procópio, Vicente Moura, Cleodon Mendes, Pedro Coda, Silva Rizza, Leofredo Duarte, Lisboa Júnior, Odilon Lyra, Gracindo Silva, A. Lanuza, Alfredo V. Lins, Gracindo Alves, Isaura Lemos, Luiz Ozório, Angeluce, Octavio Brandão, Pedro Martins, Santacruz Lima, Paulo de Santelmo, Rômulo Quaranta, Mário de Ourique, Alfredo Albuquerque, João Barros, Leon, José Máximo e José da Silva. Na documentação consultada, não encontramos a presença desses militantes operários em sociedades mutualistas de trabalhadores. Obviamente, isso não impede que eles sejam encontrados em sociedades mutualistas abertas, como veremos abaixo. É preciso ponderar, de qualquer forma, que esse breve levantamento não foi produzido de forma sistemática e, na verdade, configura-se como uma questáo que deve ser objeto de pesquisa específica para ser averiguada sua justeza.

13 Reforço, mais uma vez, que algumas evidências elencadas aqui permitem formular a questáo em nível de hipótese, que deve ser mais bem testada a partir de novos esforços de estudos empíricos.

14 Talvez não seja casual a constante identificação realizada no período entre movimento operário e "mocidade". 
aparece com o novo regime republicano termina por deixar os estados, seus bens públicos e a máquina administrativa, muito à mercê da sanha das elites e oligarquias estaduais. Assim, temos um conjunto de mudanças ocorridas após 1888/1889 que tornaram, tendencialmente, a experiência dos operários mais jovens um misto de frustração em relação às expectativas vivenciadas com o impacto degradante e explorador das condições de trabalho e de vida de fins da adolescência e início da vida adulta. Isso, junto com uma série de outras questóes, contribuiu para fazer com que o jovem proletariado engajado optasse, preferencialmente, por se associar a entidades de teor classista mais bem definido. A partir de inícios do Século XX, no caso de pensarem, também, em uma forma de proteção mútua, previdenciária, contra o descenso social, optam por participar de sociedades abertas, e não, mutuais, de características fechadas sobre um ofício ou classe. A partir de então, teríamos uma espécie de bifurcação ${ }^{15}$, que foi se concretizando lentamente, com poucos avanços consistentes e alguns significativos recuos conjunturais, numa luta pela hegemonia que, para o universo empírico maceioense que estudo, só se definiria com os comunistas a partir da segunda metade dos anos 1940 e ao longo dos anos $1950^{16}$.

Até onde permitem afirmar as pesquisas que venho realizando, essas condiçóes iniciais de ruptura e sua efetivação foram se estabelecendo em Maceió num período relativamente longo, cujos marcos iniciais foram os anos de 1890 e $1897^{17}$ e chegaram ao termo

15 Talvez fosse melhor falar em "transição" gradual, porém o termo tem sido muito carregado, ultimamente, de uma carga evolucionista, linear e etapista que desejei evitar aqui.

16 LESSA, Golbery. Uma pequena organização com uma grande influência social. In: MAJELLA, Geraldo (org.). O PCB em Alagoas: documentos (1982-1990). Maceió: s.n., 2011, pp. 303-322.

17 Período que se enquadra entre o surgimento do primeiro Partido Operário Alagoano, de vida curta, e a rearticulação da Associação Tipográfica Alagoana. Veja-se ALMEIDA, Luiz Sávio de. Crônicas Alagoanas - v. II: notas sobre poder, operários e comunistas em Alagoas. Maceió: Edufal, 2006, p. 63; MACIEL, Osvaldo. Operários em movimento: documentos para a história da classe trabalhadora em Alagoas (1870-1960). Maceió: Edufal, 2009; MACIEL, Osvaldo. Trabalhadores, identidade de classe e socialismo. Maceió: Edufal, 2009 (principalmente o terceiro capítulo). 
final na quadra que engloba o período entre 1911 e $1917^{18}$. Tal bifurcação/ruptura ocorreu, evidentemente, de modo desigual e, por vezes, descontínuo, entre categorias distintas e setores específicos e mudou para um número maior ou menor de trabalhadores, de acordo com determinadas conjunturas e/ou setores produtivos. Isso serviu de exemplo e de modelo para outras entidades de maneira mais clara ou restrita. No final desse período, de um modo ou de outro, já se configurou abalada a hegemonia mutualista e apresenta-se uma nova proposta de organização operária que, de algum modo, passou a ser tomada como a forma 'típica' de organizaçáo dos trabalhadores, daí por diante, mesmo que isso tivesse dificuldade de se efetivar na prática.

Desde então, as avaliaçôes e o 'debate' público passaram a ser realizados em função dessa 'novidade', o que reforça em que nível a disputa acontecia. As demais formas de condução e de atividades operárias que náo se coadunavam com esse novo modo de organização e de luta foram designadas, mais cedo ou mais tarde, como atrasadas, antigas ou pelegas, de modo consistente, convincente e/ou legítimo. Isto denotava que as novas condiçóes estruturais do mercado de trabalho e os padróes culturais e ideológicos que se apresentam aos contemporâneos, bem como as relaçóes sociais e as forças produtivas que determinavam a sociabilidade exigiam - também para as formas de organização da classe - essa atualização.

Uma análise histórica mais ampla da imprensa operária de Alagoas, que foca as formulaçôes político-ideológicas dos órgãos, de seus grupos e mesmo de uma mudança geracional (como já sinalizado acima), pode ajudar a entender, de maneira mais situada, as questóes que aponto aqui. Mais claramente, focarei as fricçôes surgidas entre uma postura de resistência mais aberta e classista ao projeto burguês e oligárquico, à sociedade capitalista

18 A primeira data, a de criaçăo do primeiro "sindicato" assim designado, como veremos abaixo, e a segunda, que, por si só, é uma data símbolo em nível nacional, pelo que ocorre com a experiência do jornal A Semana Social, editado por Antônio Bernardo Canellas, e a capitulação efetiva da Sociedade Perseverança e Auxílio. Veja-se MACIEL, Osvaldo. A Perseverança...,. op. cit., segundo capítulo; e MACIEL, Osvaldo (org.). A Semana Social (edição fac-símile). Maceió: Edufal, 2013. 
e os limites da formulação política de uma identidade de classe do mutualismo. Para tanto, tomarei como base a seguinte questáo: como o mutualismo passa a ser criticado abertamente pelas novas lideranças operárias que vão surgindo? Para dar resolução a esse tipo de indagação, é preciso, antes, caracterizar, de modo mais específico, o mutualismo como uma forma hegemônica de organização operária até finais do Século XIX em Maceió.

Num levantamento realizado, encontramos 24 sociedades mutualistas e congêneres em Maceió, entre os anos de 1860 e 1920, como demonstra o quadro abaixo:

Quadro 1: INSTALAÇÃO DE MUTUAIS E CONGÊNERES POR DÉCADA (MACEIÓ, 1860-1920)

\begin{tabular}{|c|c|c|c|c|c|c|}
\hline Década & $1860-9$ & $1870-9$ & $1880-9$ & $1890-9$ & $1900-9$ & $1910-9$ \\
\hline $\begin{array}{c}\text { No de mutuais } \\
\text { instaladas }\end{array}$ & 1 & 7 & 2 & 4 & 6 & 3 \\
\hline
\end{tabular}

Fonte: MACIEL, Osvaldo. A Perseverança..., op. cit., p. 47.

Como se percebe, em Maceió, o fenômeno associativo das mutuais não é dos maiores, fruto, provavelmente, de fatores mais gerais, como a população total da capital bastante reduzida, a sociabilidade pouco complexificada etc. Por esses dados, podemos perceber, também, que há uma oscilação negativa entre a última década do Império e a primeira da República, talvez devido à instabilidade provocada pela mudança de regime. Com alguma precauçáo, podemos sinalizar com uma retomada do crescimento na primeira década do Século XX, seguida de uma redução drástica posterior.

Do total geral de mutuais e assemelhadas encontradas, 13 sáo sociedades de auxílio mútuo organizadas por trabalhadores (artífices, operários), como segue abaixo: 
Quadro 2: SOCIEDADES MUTUAIS DE TRABALHADORES (MACEIÓ, 1869-1923)

\begin{tabular}{|l|l|}
\hline DENOMINAÇÃo & DURAÇÃo \\
\hline Associação Tipográfica Alagoana de Socorros Mútuos & $1869-1897$ \\
\hline $\begin{array}{l}\text { Sociedade Beneficente de Proteção e Auxílio (dos em- } \\
\text { pregados e operários da Fábrica de Tecidos da Cia. União } \\
\text { Mercantil) }\end{array}$ & 1876 \\
\hline Sociedade Recreio Filarmônico & $1876-90$ \\
\hline Sociedade Montepio São José de Maceió & $1876-81$ \\
\hline Sociedade Perseverança e Auxílio dos Caixeiros de Maceió & $1879-c .195 \ldots$ \\
\hline Sociedade de Instrução e Amparo dos Caixeiros de Maceió & $1882-4$ \\
\hline Associação Montepio dos Artistas Alagoanos & $1883-$ c.196... \\
\hline Sociedade dos Artistas de Maceió [?] & 1890 \\
\hline Sociedade Filarmônica dos Artistas de Maceió [?] & 1890 \\
\hline Montepio dos Alfaiates & 1898 \\
\hline Monte-Pio dos Operários Cigarreiros de Maceió & 1899 \\
\hline Sociedade Beneficente Postal & 1911 \\
\hline Sociedade União dos Operários Trapicheiros de Maceió & 1923 \\
\hline
\end{tabular}

Fonte: MACIEL, Osvaldo. A Perseverança..., op. cit., p. 49.

Em que pese o número reduzido de mutuais abertas, no que toca às mutuais de trabalhadores, esse não é um fenômeno negligenciável, considerando o caso de Maceió, e deve ser levando em consideração quando se pretende estudar as origens do movimento operário no Estado. Entre as entidades aqui elencadas, 
destacaria três pela importância e pela duração de suas atividades: a Associaçáo Tipográfica Alagoana de Socorros Mútuos, a Sociedade Perseverança e Auxílio dos Caixeiros de Maceió e o MontePio dos Artistas Alagoanos, sendo que essas duas últimas estenderam suas existências, pelo menos, até meados do Século XX.

Salvo engano, ao longo de todo o Século XIX, não há registro algum, para o caso maceioense, de crítica a essa nova forma de organização e associação de pessoas, muito em particular, de trabalhadores. Para o Brasil, em geral, pode-se afirmar que não há oposição explícita à criação e à institucionalização das mutuais de trabalhadores. Talvez isso se deva, particularmente, ao modo como essas mutuais foram institucionalizadas, às articulaçóes necessárias para concretizar tal processo, contando, inclusive, com o beneplácito do governo imperial ou provincial para seu funcionamento regular, inclusive, levando-se em conta a reforma dos costumes necessária a uma sociedade que, gradativamente, abandonava o escravismo e abraçava sem pressa as formas de trabalho remunerado.

Com o surgimento de organizaçóes operárias de corte classista e do movimento operário, em seu sentido moderno, foi que os princípios e as bases da organizaçáo mutual dos trabalhadores passaram a ser atacados. Em Maceió, a primeira fase dessa crítica aconteceu com o surgimento de entidades como a Associação Tipográfica Alagoana, recriada em 1897, e com nítidas características de resistência; o Centro Proletário Alagoano (1900-1903) e a já referida União Operária Alagoana. Com a recepção e a elaboração de um discurso socialista de crítica ao mundo burguês e capitalista, teríamos a superação gradual, evolutiva e reformista da sociedade como um todo. No mundo do trabalho, essa evoluçáo se configuraria em termos de mudança na forma de organizar os trabalhadores. Um bom espelho dessas transformaçóes foi o grupo de João Ferro de Oliveira, que é composto, ainda, por José Grevy, Norberto Carlos, Olympio Sant'Anna e outros, em torno do qual surgiram as entidades citadas acima, além de vários órgáos da imprensa operária local. Dentre alguns dos principais órgãos, podemos citar $O$ Trocista, O Artista, A Palestra, A Imprensa, 
O Mensageiro, O Baluarte, O Escravo Livre, O Trabalho, O Proletário, entre outros ${ }^{19}$. $\mathrm{O}$ último desses, $O$ Proletário, denominado de Órgão das classes trabalhadoras do Estado de Alagoas, tem como objetivo principal defender a criação de um núcleo de resistência no interior da atividade operária. Nesses termos, o periódico advoga:

Necessitamos de uma associação francamente socialista, fundada sobre bases sólidas e estáveis, segundo os princípios modernos, adotados no mundo inteiro.

As associaçóes de beneficência operária, nessa terra, nenhum resultado prático tem dado.

A ideia de beneficência ficará a cargo da consciência de cada um. Portanto, operários, unidos, estreitamente ligados pelos laços de solidariedade, lancemos as bases de uma agremiação proletária, futuro baluarte inexpugnável do nosso ideal ${ }^{20}$.

Foi nesse período em que os assalariados de Maceió começaram a fazer um uso diverso do mutualismo. No contexto do final da escravidão, com o advento da República, o surgimento da indústria têxtil e o início da reconfiguração do processo de produção agro-canavieiro, houve um aumento no nível de proletarização das classes subalternas. Esse fenômeno, vivido mais intensamente pela mocidade, na transição entre os Séculos XIX e XX em Maceió, como já indicado, não só ajuda a entender a reorganização da Associação Tipográfica Alagoana com caráter sindical mais claro, como também o surgimento do movimento operário em sentido estrito, como assinalado. Ao mesmo tempo, ele contribui para entender o surgimento, a ampliação e a importância de mutuais abertas no contexto mais geral do mutualismo local. Aqui, parece-me, a funçáo previdenciária da mutual é que prevalece, em detrimento de questóes identitárias e de outras. Esse contexto favoreceu o surgimento de mutuais abertas. Uma

19 MACIEL, Osvaldo. Trabalhadores..., op. cit.

20 [sem título]. O Proletário. Maceió, Ano I, n 1, 17 de janeiro de 1902, p. 1. Grifos nossos. 
delas foi a Sociedade Gladiantes, que surgiu em 1896 e logo desapareceu. Porém foi reorganizada em meados de 1903. Seus principais objetivos eram de instruir e fazer caridade. Segundo seu órgão de divulgação, em outubro de 1903, a entidade tinha 632 sócios e chegou a mais de 1200 no final daquele mesmo $\mathrm{ano}^{21}$. Outra seria a Sociedade Mutuária e Previdência. No relatório da diretoria, realizado em 1902, indica-se que a entidade contava com 837 sócios - 528 homens e 309 mulheres $^{22}$.

Essas duas sociedades, junto com a Luzeiro da Caridade, a Sociedade Burocrática Beneficente e a Sociedade Casamento e Mortalha, entre outras, parecem ocupar o principal papel de mutualidade como sociedades abertas a partir do início do Século $\mathrm{XX}$ em Alagoas, inclusive pelo fato de náo se restringirem a um município e abranger várias regiōes do Estado, com seçóes em diversos municípios do interior. Nesses termos, pode-se pensar na possibilidade de que, num momento de crise ou de fechamento das sociedades mutuais de trabalhadores em função de diversas questóes, mas, principalmente financeiras, as mutuais abertas terminam capitalizando em torno de seus princípios amplos, suas joias, mensalidades baixas e seus serviços básicos (auxílio a doenças e aos funerais, pensão na viuvez ou invalidez, eventuais reuniōes festivas etc.). É interessante encontrar, em seus quadros sociais, alguns dos militantes engajados na causa operária ou socialista do período, como Guilherme Lemos, Virgínio de Campos, Olímpio Leonídio, entre outros.

Segundo o Secretário de Estado dos Negócios do Interior, esse "espírito associativo" era decorrência da evolução social e das "tendências altruístas e reformadoras" da civilização. Por isso que, em Alagoas, via-se desenvolver e consolidar a "grandiosa e humanitária ideia do auxílio mútuo e do socorro recíproco", refletida nas sociedades Burocrática Beneficente, Previdência Alagoana,

21 Número de sócios “Gladiantes”. O Gladiante, Maceió, ano I, nº 1, 15 de novembro de 1903, p. 3. [Arquivo Público Estadual Jordão Emerenciano - Apeje]

22 S. M. Previdência - O relatório da Diretoria. Gutenberg, Maceió, ano XXI, no 21, 31 de janeiro de 1902, p. 2. Provavelmente essa sociedade seja também designada, em outras fontes, com o nome de Previdência Alagoana. [Instituto Histórico e Geográfico de Alagoas - IHGA] 
Monte-Pio dos Artistas Alagoanos, Gladiantes, Luzeiro da Caridade, Cavalheiros da Beneficência, Casamento e Mortalha, Mutualidade Alagoana, Perseverança e Auxílio dos Empregados no Comércio de Maceió e Sociedade Beneficente Postal. Para o Secretário, essas agremiaçóes "conspiram e dáo combates contra os revezes da sorte" náo apenas aos que vivem do "penoso e suarento labor" e esquecem-se de poupar uma parcela de seus ganhos, mesmo que "diminuta", mas também aos que, acreditando na "falaz e leda persuasão da perenidade da fortuna", viveriam "uma vida efêmera, [onde] tudo dissipam"23. Ou seja, o governo reconhecia que o associativismo mutual não era um movimento só dos trabalhadores assalariados, mas também dos extratos sociais mais altos da sociedade, que tentavam prevenir o descenso.

Qualquer que seja a leitura realizada acerca do fenômeno, a precarização das condiçóes de existência e de reprodução da sociedade possibilitou o surgimento do movimento operário, no sentido clássico do termo, e reconfigurou o modo como os trabalhadores e as camadas empobrecidas da sociedade recorriam às mutuais, aproximando-se de mutuais abertas.

Não obstante a crítica que já era feita ao mutualismo operário nessa primeira conjuntura, foi na vaga ocorrida entre o final de 1911 e 1917 que a hegemonia mutualista dos trabalhadores organizados em Maceió passou por um questionamento organicamente articulado, a partir de fatores que operam no seio do próprio conjunto mais amplo dos que eram chamados de filhos do trabalho. Dentre tais fatores, destacamos a presença da Confederação Operária Brasileira e a guerra mundial, que pôs fim a uma era, segundo Hobsbawm24. Junta-se a esses fatores a própria dinâmica da sociabilidade maceioense/alagoana, como pode ser percebido com o fim traumático de uma oligarquia e

23 Relatório apresentado ao Exmo. Snr. Bacharel Euclides Vieira Malta, Governador do estado de Alagoas, pelo Bacharel Bernardino de Senna Ribeiro, Secretário de Estado dos Negócios do Interior, no dia 31 de março de 1910 [continuação]. In: A Tribuna, Maceió, ano XVI, no 4291, 27 de outubro de 1911, p. 1. [IHGA].

24 HOBSBAWM, Eric J. A era dos impérios (1875-1914). Tradução de Sieni Maria Campos e Yolanda Steidel de Toledo/ Revisão técnica de Maria Célia Paoli. Rio de Janeiro: 11. ed., Paz e Terra, 2007. 
o surgimento de outra (fins de 1911/meados de 1912)25, verdadeiro acontecimento político-administrativo para o Estado, o que nos leva a pensar na clássica ideia de que, quando os de cima brigam, os de baixo aproveitam para ampliar suas condiçóes de barganha, avançando em suas demandas no que é possível. Nesse período, observa-se também a presença de fraçóes de trabalhadores organizados em mutuais no Quebra dos terreiros de Xangô, em fevereiro de 1912, o que gerou uma cisão no nível do espaço público entre camadas populares e trabalhadores organizados e promoveu uma crise de legitimidade entre artistas e operários, em meio ao conjunto dos grupos subalternizados, que não mais seria contornada. Aliam-se a isso o surgimento do primeiro sindicato, em outubro de 1911 (o Sindicato Gráfico Alagoano), e a leva corrente de surgimento de outros sindicatos articulados em torno da Federação Operária Alagoana, fundada em $1^{\circ}$ de maio de 1913. Entre tais sindicatos, encontram-se náo só o Sindicato Gráfico, mas também o dos alfaiates, dos sapateiros, dos estivadores, dos marceneiros, dos tecelóes das fábricas localizadas na Cachoeira e em Rio Largo, além dos sindicatos dos padeiros, dos trapicheiros e dos pedreiros 26.

Até os finais da primeira década do novo século, ou seja, até antes dessa leva de mobilizaçáo operária (1911-1917), tem-se a impressão de que a luta de classes promovida pelos operários não assombrava as autoridades e as classes dominantes. Um exemplo disso encontra-se no tópico sobre a Ordem Pública contido no relatório do governo estadual de 1909, onde se registra a greve realizada na companhia ferroviária Great Western:

Houve apenas um momento em que ele ["o povo alagoano"] pressentiu uma catástrofe, foi

25 TENÓRIO, Douglas Apratto. A metamorfose das oligarquias. Maceió: HD Livros, 1997.

26 Federação Operária. Jornal de Alagoas, Maceió, ano VI, no 95, 9 de maio de 1913, p. 2 [IHGA]; Relatório da 'Federaçáo Operária de Alagoas' enviado ao Centro Libertário de S. Paulo para ser apresentado no Congresso Internacional Anarquista de Londres (1915) [29/ago a 6/set próximo (1915?)] [Centro de Documentação e Memória da Universidade Estadual Paulista - Cedem-Unesp]. Nessas fontes, aparecem vários nomes de militantes, alguns novos e outros já com longa tradição de lutas. 
quando irrompeu no dia 13 de janeiro desse ano a greve dos empregados da Great Wester, que abrangendo esse Estado e os de Pernambuco, Paraíba e Rio Grande do Norte, a todos pareceu de gravíssimas consequências.

Mas o espírito de ordem e mansidão que presidiu a mesma greve desde o seu começo e as medidas de garantia tomadas pelos Governos da República e dos ditos Estados, salientando-se o Governador de Pernambuco, sede do movimento, pelas propostas de conciliaçáo que esposou, produziram o feliz término dessa anormalidade em 24 do referido mês, término que aqui foi recebido com as maiores demonstraçóes de regozijo popular27.

No mesmo relatório, no item sobre Segurança Individual e de Propriedade, tal posição fica mais clara ainda. Nele, o governador em exercício começou lamentando que "centros civilizados [referindo-se aos centros mais avançados do país], cuja intensidade de instruçáo corre parelhas com o acúmulo de suas riquezas", produzissem assassinos e criminosos nas "camadas superiores", de "apuro moral e intelectual". De qualquer modo, essa visão termina enchendo-o de "justificado amor próprio" posto que "o nosso Estado não registra em seus anais os repetidos crimes que estão se dando fora de nós, fazendo estremecer de emoção e de horror uma sociedade inteira" 28 .

Ao que parece, a postura do governo alagoano em relação ao movimento operário, como um todo, e aos momentos fortes de reivindicação e organização dos trabalhadores só mudou na

27 RELATÓRIO com que, ao Exmo. Snr. Coronel José Miguel de Vasconcelos, vice-governador, passou a administraçáo do Estado o Exmo. Snr. Dr. Euclides Vieira Malta, governador, no dia 3 de março de 1909. Maceió: Tipografia e Papelaria de Tavares Irmãos \& Ca., 1909, p. 3-4. Para mais detalhes sobre essa greve, consultar: ALMEIDA, Luiz Sávio de. A greve dos ferroviários em 1909. In: Chrônicas..., op. cit., p. 89-108.

28 RELATÓRIO com que, ao Exmo. Snr. Coronel José..., op. cit., p. 4. Esse item vem logo após o comentário sobre a greve na Great Western. E aqui é interessante a sugestáo que o vice-governador estabelece com o anarquismo e a violência do sindicalismo revolucionário. 
segunda metade da segunda década do Século XX e passaram a ser exercidas uma perseguição e uma violência até entáo inéditas. Seria a reação governamental à força da mobilização e crítica que os operários organizados e suas lideranças vinham realizando contra as autoridades estaduais e municipais, as políticas públicas e a própria sociedade capitalista. Certamente influi nisso a experiência vivenciada pelas elites em outras regiôes do país e no exterior, particularmente com a Revolução Russa de 1917, que terminou por ensinar à burguesia tanto a precauçáo quanto novas formas de coerção e de violência para com o operariado.

Em finais de 1920, por exemplo, o nível de repressão e de violência foi muito mais forte do que o que se vinha encontrando em outras conjunturas locais anteriores. Nesse sentido, alguns artigos da imprensa operária falavam em reação das autoridades aos protestos populares com "patas de cavalo e chanfalho policial no lombo" 29 . Em funçáo do recrudescimento do tratamento que o governo dispensava ao movimento, $O$ Escravo perguntava: "Por que os soldados atiram contra os trabalhadores, sendo também pobre escravo da disciplina e do capital?”. E em resposta à própria pergunta, sugeria: "- Pela ignorância...."30.

No fulcro da leva de mobilizaçáo operária articulada pela Federaçáa Operaria Alagoana e na reação estatal a essa conjuntura de intensa mobilização, vimos a comparação entre as formas mutuais e classistas de organizaçáo operárias que eram acionadas como recurso de identificaçáo e de elaboraçáo de uma nova postura político-ideológica para o operariado.

Em que pese o caráter acentuadamente dirigido de sua visáo na construção do relatório sobre as condições de vida, de trabalho e mobilizaçáo do operariado alagoano, a Federação Operária de Alagoas afirmou, em 1915, que "o povo trabalhador" encontravase "desiludido dos sistemas de associaçoóes operárias de caráter beneficente ou mutuária e das promessas burguesas que incitavam os operários a votarem nos candidatos políticos, para, por esse

\footnotetext{
29 Quem somos. O Escravo, Maceió, ano I, no 1, 28 de outubro de 1920, p. 1-2. [Cedem-Unesp].

30 [sem título]. O Escravo, Maceió, ano I, n 1, 28 de outubro de 1920, p. 2. [Cedem-Unesp].
} 
meio, conseguirem a sua emancipação" 31 . Nesse mesmo período, Alfredo V. Lins, numa exortação à união dos operários, sugeria um momento de degenerescência das organizaçóes anteriores dos trabalhadores, particularmente por causa de seu apoio à "política de partidos", afirmando que o sindicalismo era "consequência da obra de regeneração" que vinha ocorrendo nos últimos anos ${ }^{32}$. Já na coluna "Vida Operária” existente no já citado periódico O Escravo, noticiava-se, com regularidade, uma série de eventos e atividades que apresentavam a vida orgânica e movimentada para muitas entidades de trabalhadores, como a União dos Trabalhadores em Madeira, a Uniāo dos Padeiros, a Associação dos Alfaiates e a União dos $\mathrm{O}$ [perários] Lancheiros. A coluna ainda apontara a vivacidade da "potente organização" que era a União dos Padeiros; indicara a reorganização da "legião dos lancheiros", depois de um período em que foi desarticulada pelas forças "do Capital e do Estado", e sugerira que a entidade dos alfaiates, à medida que ia mudando o perfil composicional de seus sócios (de autônomos e pequenos negociantes para assalariados), abandonava sua orientação assistencial e mutualista para tomar "moldes sindicalistas" 33 .

\section{CONSIDERAÇÓES FINAIS}

Quando o Estado começou a promover algumas políticas de seguridade social e de previdência para algumas das categorias de trabalhadores no Brasil, por mais precárias, irregulares e insuficientes que fossem, elas acabam levando a débâcle de muitas das sociedades mutualistas organizadas por ou voltadas, primordialmente, para os trabalhadores. Em Alagoas, como já assinalado, esse fenômeno não foi tão brusco e acentuado como o ocorrido em outros lugares do país. No entanto, as mutuais e beneficentes que continuam sobrevivendo o fazem em nível residual ao papel que exerceram até então. $\mathrm{O}$ mutualismo passou a ser criticado,

31 Relatório da Federaçáo Operária..., op. cit. [Cedem-Unesp].

32 LINS, Alfredo V. Avante! O Rebate, Maceió, $1^{\circ}$ de maio de 1915, ano I, no 1, p. 1. [Cedem-Unesp]

33 Vida operária. O Escravo, Maceió, ano I, n 1, 28 de outubro de 1920, p. 3. [Cedem-Unesp]. 
desde então, entre lideranças legítimas de trabalhadores, de forma até entâo inimaginável.

Devido a tudo isso, conforme se argumenta nessas páginas, parece ser necessário afirmar que a experiência histórica do mutualismo em Maceió diminui suas possibilidades de contribuir para o entendimento das formas de organizaçáo da classe trabalhadora nas primeiras duas décadas do Século XX. A partir daí, o fenômeno pode nos ajudar, no máximo, a entender como esse processo de formação se tornou mais demorado e difícil, na medida em que algumas mutuais foram criadas posteriormente a esse período, e outras poucas se mantiveram em funcionamento, ora capitalizando em torno de si uma tradição e um histórico associativo, com momentos de fortalecimento do quadro social, ora prolongando seu definhamento através de alianças com líderes oportunistas ou em momentos pontuais de comemoraçáo, em que seus diretores e militantes olhavam para trás como se quisessem reviver a idade do ouro. Ressalte-se, porém, que essa avaliação formulada no início do parágrafo precisa de seu corolário: outros tipos de organização passaram, num primeiro momento, a questionar tal hegemonia mutualista no desenvolvimento da organizaçáo dos trabalhadores e, num segundo momento que, muitas vezes, é coetâneo para determinadas categorias - tornamse alternativas concretas na construçáo de uma nova hegemonia interna no modo como os operários e os trabalhadores em geral se organizam.

Finalizamos este estudo de caráter ensaístico, reforçando que muitas das ideias aqui contidas precisam ser consolidadas em estudos específicos sobre alguns de seus pontos. A partir do caso maceioense, espero ter oferecido uma proposta mais geral de entendimento do papel do mutualismo no processo de organizaçáo dos trabalhadores e de construção de sua tradição de lutas e embates ao longo da chamada Primeira República brasileira, em especial, do Nordeste. 


\section{REFERÊNCIAS}

ALMEIDA, Luiz Sávio de. Crônicas Alagoanas, v. II: notas sobre poder, operários e comunistas em Alagoas. Maceió: Edufal, 2006.

BATALHA, Cláudio. Sociedades de trabalhadores no Rio de Janeiro do Século XIX: algumas reflexôes em torno da formação da classe operária. In: Cadernos AEL: Sociedades operárias e mutualismo. Campinas, v.6, n.10/11, p.41-66, 1999.

GRAMSCI, Antonio. Caderno 13 (1932/4): Breves notas sobre a política de Maquiavel. In: Cadernos do cárcere, v.3 (editor: Carlos Nelson Coutinho). Traduçáo de Luiz Sérgio Henriques, Marco Aurélio Nogueira e Carlos Nelson Coutinho. Rio de Janeiro: Civilização Brasileira, 2000, p.13-109.

HOBSBAWM, Eric. A era dos impérios (1875-1914). 11.ed. Tradução de Sieni Maria Campos e Yolanda Steidel de Toledo. Revisão técnica de Maria Celia Paoli. Rio de Janeiro: Paz e Terra, 2007.

LESSA, Golbery. Uma pequena organização com uma grande influência social. In: MAJELLA, Geraldo (org.). O PCB em Alagoas: documentos (1982-1990). Maceió: s.n., 2011, p. 303-322.

MACIEL, Osvaldo (org.). A Semana Social (edição fac-símile). Maceió: Edufal, 2013.

MACIEL, Osvaldo. A Perseverança dos caixeiros: o mutualismo dos trabalhadores do comércio em Maceió (1879-1917). Recife: Edufpe, 2011.

MACIEL, Osvaldo. Operários em movimento: Documentos para a história da classe trabalhadora em Alagoas (1870-1960). Maceió: Edufal, 2009. 
MACIEL, Osvaldo. Trabalhadores, identidade de classe e socialismo. Maceió: Edufal, 2009.

MATTOS, Marcelo Badaró. Escravizados e livres: experiências comuns na formação da classe trabalhadora carioca. Rio de Janeiro: Bom Texto, 2008.

MATTOS, Marcelo Badaró. Novos e velhos sindicalismos: Rio de Janeiro, 1955-1988. Rio de Janeiro: Vício de Leitura, 1998.

TENÓRIO, Douglas Apratto. A metamorfose das oligarquias. Maceió: HD Livros, 1997.

THOMPSON. Edward P. Patrícios e plebeus. In: Costumes em comum: estudos sobre a cultura popular tradicional. Tradução de Rosaura Eichemberg - São Paulo: Cia das Letras, 1998, p.56-64.

VISCARDI, Cláudia Maria Ribeiro; JESUS, Ronaldo Pereira de. A experiência mutualista e a formaçáo da classe trabalhadora no Brasil. In: FERREIRA, Jorge; REIS FILHO, Daniel Aarão (orgs). As esquerdas no Brasil, v. 1 - A formação das tradiçôes (1889-1945). Rio de Janeiro: Civilização Brasileira, 2007, p.21-51.

VITORINO, Artur José Renda. Máquinas e operários: mudança técnica e sindicalismo gráfico (São Paulo e Rio de Janeiro, 1858-1912). Sáo Paulo: Annablume; Fapesp, 2000.

\section{FRAGMENTOS HISTÓRICOS DE ARTIGOS DE JOR- NAIS E RELATÓRIOS}

[sem título]. O Escravo, Maceió, ano I, $\mathrm{n}^{\circ} 1,28$ de outubro de 1920, p. 2. [Centro de Documentação e Memória da 
Universidade Estadual Paulista - Cedem-Unesp]

[sem título]. O Proletário. Maceió, Ano I, no 1,17 de janeiro de 1902, p. 1. [Centro de Documentação e Memória da Universidade Estadual Paulista - Cedem-Unesp]

Federação Operária. Jornal de Alagoas, Maceió, ano VI, n ${ }^{\circ}$ 95, 9 de maio de 1913, p. 2 [Instituto Histórico e Geográfico de Alagoas - IHGA]

LINS, Alfredo V. Avante! O Rebate, Maceió, $1^{\circ}$ de maio de 1915, ano I, no 1, p. 1. [Centro de Documentaçáo e Memória da Universidade Estadual Paulista - Cedem-Unesp].

Número de sócios "Gladiantes". O Gladiante, Maceió, ano I, $n^{\circ}$ 1, 15 de novembro de 1903, p. 3. [Arquivo Público Estadual Jordão Emerenciano - APEJE]

Quem somos. O Escravo, Maceió, ano I, $\mathrm{n}^{\circ} 1,28$ de outubro de 1920, pp. 1-2. [Centro de Documentaçáo e Memória da Universidade Estadual Paulista - Cedem-Unesp].

Relatório apresentado ao Exmo. Snr. Bacharel Euclides Vieira Malta, Governador do Estado de Alagoas, pelo Bacharel Bernardino de Senna Ribeiro, Secretário de Estado dos Negócios do Interior no dia 31 de março de 1910 [continuação]. In: A Tribuna, ano XVI, no 4291, 27 de outubro de 1911, p. 1. [Instituto Histórico e Geográfico de Alagoas - IHGA].

RELATÓRIO com que ao Exmo. Snr. Coronel José Miguel de Vasconcelos, vice-governador, passou a administraçáo do Estado ao Exmo. Snr. Dr. Euclides Vieira Malta, governador, no dia 3 de março de 1909. Maceió: Tipografia e Papelaria de Tavares Irmãos \& Ca., 1909.

Relatório da 'Federaçáo Operária de Alagoas', enviado ao 
Centro Libertário de S. Paulo para ser apresentado no Congresso Internacional Anarquista de Londres (1915) [29/ago a 6/set próximo (1915?)]. [Centro de Documentação e Memória da Universidade Estadual Paulista - Cedem-Unesp].

S. M. Previdência - O relatório da Diretoria. Gutenberg, Maceió, ano XXI, no 21, 31 de janeiro de 1902, p. 2. [Instituto Histórico e Geográfico de Alagoas - IHGA].

Vida operária. O Escravo, Maceió, ano I, n ${ }^{\circ} 1,28$ de outubro de 1920, p. 3. [Centro de Documentação e Memória da Universidade Estadual Paulista - Cedem-Unesp]. 